\title{
FAKTOR-FAKTOR YANG MEMENGARUHI KEHAMILAN TIDAK DIINGINKAN DI INDONESIA TAHUN 2017
}

(Factors Affecting Unintended Pregnancy in Indonesia 2017)

\author{
Febriana ${ }^{1}$, Liza Kurnia Sari ${ }^{2}$ \\ Politeknik Statistika STIS ${ }^{1}$ \\ Politeknik Statistika STIS 2 \\ Jl. Otto Iskandardinata No. 64c, RT.1/RW.4, Jakarta Timur, DKI Jakarta \\ E-mail: 16.9131@stis.ac.id
}

\begin{abstract}
ABSTRAK
Kehamilan tidak diinginkan (KTD) terdiri dari kehamilan tidak tepat waktu dan kehamilan tidak diinginkan sama sekali. KTD dapat menyebabkan kelahiran yang tidak direncanakan dan dapat mengganggu kesehatan fisik dan mental ibu dan anak. KTD juga merupakan indikator peningkatan risiko kelahiran yang buruk seperti kelahiran prematur, ketuban pecah dini, dan bayi berat lahir rendah, serta dapat menyebabkan keguguran. Selain itu, KTD juga dapat menyebabkan kematian ibu. Dengan banyaknya permasalahan yang disebabkan oleh KTD, peneliti ingin mengetahui faktor-faktor yang memengaruhi KTD pada wanita usia subur di Indonesia dengan menggunakan data SDKI 2017. Dengan menggunakan analisis regresi logistik multinomial, didapatkan hasil bahwa umur ibu, jumlah anak masih hidup, penggunaan kontrasepsi, status pernikahan, wilayah tempat tinggal, dan pendidikan ibu memengaruhi KTD. Kecenderungan wanita mengalami mistimed pregnancy lebih tinggi terjadi pada wanita yang berusia $<20$ tahun, memiliki lebih dari 3 orang anak, menggunakan kontrasepsi, belum menikah, tinggal di perkotaan, dan pendidikan tertinggi >SMA. Sedangkan, kecenderungan wanita mengalami kehamilan tidak diinginkan sama sekali lebih tinggi terjadi pada wanita yang berusia >35 tahun, memiliki minimal 3 anak, menggunakan kontrasepsi, belum menikah, tinggal di daerah perkotaan, dan pendidikan tertinggi SMP atau SMA.
\end{abstract}

Kata kunci: wanita usia subur, regresi logistik multinomial, kehamilan tidak diinginkan

\section{ABSTRACT}

Unintended pregnancies consist of mistimed pregnancies and pregnancies that are not wanted at all. Unintended pregnancies can lead to unplanned births and can interfere with the physical and mental health of both mother and child. Unintended pregnancies is also an indicator of an increased risk of poor births such as preterm birth, premature rupture of membranes and low birth weight babies, and can lead to miscarriage. In addition, unintended pregnancies is also related to maternal mortality. With the many problems caused by unintended pregnancies, researchers wanted to know the factors that influence unintended pregnancies in women of childbearing age in Indonesia using the 2017 IDHS data. Marital status, area of residence, and mother's education affect unintended pregnancies. The trisk of women to experience mistimed pregnancy is higher among women aged $<20$ years, have $\geq 3$ children, use contraception, are not married, live in urban areas, and have the highest education> SMA. Meanwhile, the risk for women to experience unwanted pregnancy is higher in women aged> 35 years, have at least 3 children, use contraception, are not married, live in urban areas, and have the highest education in junior high or high school.

Keywords: woman of childbearing age, multinomial logistic regression, unintended pregnancy

\section{PENDAHULUAN}

Salah satu tujuan dalam berumah tangga adalah untuk melanjutkan keturunan yaitu dengan melalui proses kehamilan. Kehamilan merupakan keadaan dimana seorang wanita yang di dalam rahimnya terdapat embrio dan kemudian berkembang menjadi janin. Lamanya kehamilan diperkirakan sekitar 40 minggu dan tidak melebihi 43 minggu (Kuswanti, 2014 dalam Fitriani, 2017). Terjadinya kehamilan merupakan suatu hal luar biasa bagi seorang wanita sebagai salah satu fase kehidupan dan fase reproduksi manusia untuk mendapatkan keturunan. Namun, pada kenyataannya tidak semua kehamilan merupakan kehamilan yang diinginkan. Karena masih terdapat kehamilan yang tidak diinginkan. 
Kehamilan yang diinginkan terjadi pada pasangan yang memang menginginkan anak dan pada saat waktu yang tepat. Kehamilan tidak diinginkan (KTD) terdiri dari kehamilan yang tidak tepat waktu (mistimed pregnancy) dan kehamilan yang tidak diinginkan sama sekali (unwanted pregnancy). Kehamilan yang tidak tepat waktu terjadi ketika wanita menginginkan anak di masa yang akan datang, namun kehamilan terjadi lebih cepat dari yang direncanakan. Kehamilan yang tidak diinginkan sama sekali merupakan kehamilan yang terjadi pada wanita yang telah memiliki anak dan tidak menginginkannya lagi (Islam dan Rashid, 2005).

Kejadian KTD banyak terjadi di dunia. Menurut Sedgh et al (2014), ada sekitar 210 juta kehamilan di dunia pada tahun 2012 dan 85 juta dari kehamilan tersebut merupakan KTD. Berdasarkan hasil Survei Demografi dan Kesehatan Indonesia (SDKI) pada tahun 2017, dari semua kelahiran dalam 5 tahun terakhir dan semua kehamilan pada saat survei, sebesar 84 persen merupakan kehamilan yang diinginkan, 8 persen merupakan kehamilan yang tidak tepat waktu, dan 7 persen merupakan kehamilan yang tidak diinginkan terjadi di Indonesia (SDKI, 2017).

Wanita yang mengalami KTD dapat mengambil keputusan tindakan terhadap kehamilannya. Ada yang memutuskan tetap melanjutkan kehamilannya, menggugurkannya dengan sengaja, atau mengalami keguguran setelah memutuskan tetap melanjutkan kehamilannya. Ketika wanita memutuskan untuk tetap melanjutkan kehamilannya, maka akan menyebabkan terjadinya kelahiran yang tidak direncanakan. KTD dapat menjadi indikator peningkatan risiko untuk beberapa kelahiran yang buruk seperti kelahiran prematur, ketuban pecah dini, dan melahirkan bayi dengan berat badan lahir rendah (Mohllajee et al, 2007). Permasalahan ini dapat terjadi karena pada umumnya ibu yang mengalami KTD tidak melakukan perawatan yang maksimal selama masa kehamilan dan terhadap bayinya setelah melahirkan. Hal tersebut diakibatkan karena ibu yang mengalami KTD pada umumnya berharap kehamilannya tidak akan berlanjut (Dini et al,2016).

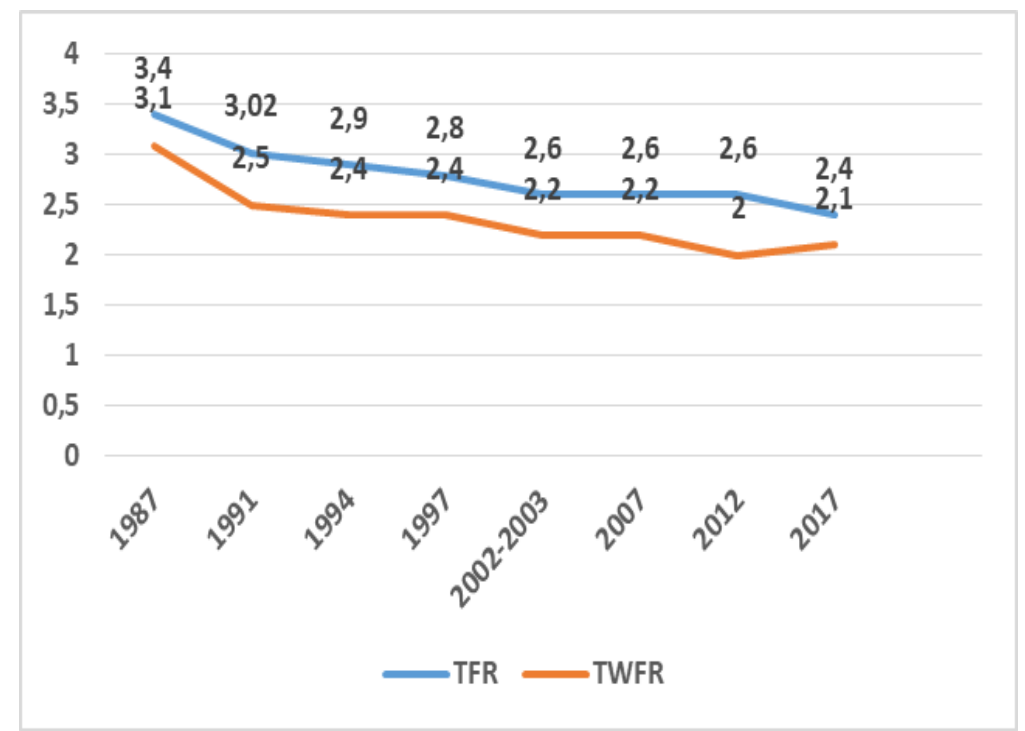

Sumber : SDKI 1987-2017, diolah

Gambar 1. TFR dan TWFR di Indonesia tahun 1987-2017

Berdasarkan Gambar 1, angka kelahiran total (TFR) di Indonesia secara umum lebih tinggi dibandingkan dengan angka kelahiran yang diinginkan (TWFR). TWFR mencerminkan angka fertilitas yang akan terjadi jika semua kelahiran yang tidak diharapkan dapat dicegah. TFR di Indonesia pada tahun 2017 sebesar 2,4, artinya setiap wanita usia subur memiliki 2-3 anak. Angka ini lebih besar dibandingkan dengan angka TWFR yang bernilai 2,1. Perbedaan ini berarti jika jumlah KTD yang dapat menyebabkan kelahiran tak direncanakan berkurang, maka nilai TFR juga dapat diturunkan.

Wanita yang tidak melakukan perawatan selama kehamilan dengan maksimal mempunyai kemungkinan mengalami keguguran (abortus spontan). Keguguran dapat terjadi karena secara psikososial ibu belum siap atas kehamilannya. Keadaan ini berdampak pada kesehatan fisik yang menunjang untuk melangsungkan kehamilan sehingga mengakibatkan keguguran. Menurut Sedgh 
et al (2014), jumlah ibu hamil yang mengalami keguguran diperkirakan sekitar 20 persen dari total kelahiran hidup di dunia. Dari beberapa peneltian juga telah terbukti bahwa resiko terjadinya keguguran mengalami peningkatan di antara kehamilan yang tidak diinginkan (Gipson et al,2008 dalam Sedgh et al, 2014).

Keputusan tindakan terakhir yang dilakukan oleh wanita yang mengalami KTD adalah menggugurkan kandungan (aborsi dengan sengaja). Fenomena aborsi sudah tidak asing di kalangan masyarakat Indonesia. Banyak aborsi tidak aman yang dilakukan di Indonesia. Secara keseluruhan, hampir setengah dari semua perempuan yang mencari pelayanan aborsi di Indonesia lari pada dukun bersalin, dukun tradisional atau ahli pijat yang menggunakan cara pemijatan untuk menggugurkan kandungan. Sementara itu, hampir setengah dari perempuan yang memilih upaya aborsi di klinik kesehatan terlebih dahulu melakukan upaya aborsi sendiri dengan meminum jamujamuan dan obat-obatan tanpa resep (Sedgh dan Ball, 2008).

Aborsi dengan cara yang tidak aman dapat menyebabkan kematian ibu. Menurut laporan dari WHO (2014), kematian ibu umumnya terjadi akibat komplikasi saat dan pasca kehamilan. Adapun jenis-jenis komplikasi yang menyebabkan mayoritas kasus kematian ibu - sekitar $75 \%$ dari total kasus kematian ibu - adalah pendarahan, infeksi, tekanan darah tinggi saat kehamilan, komplikasi persalinan, dan aborsi yang tidak aman.

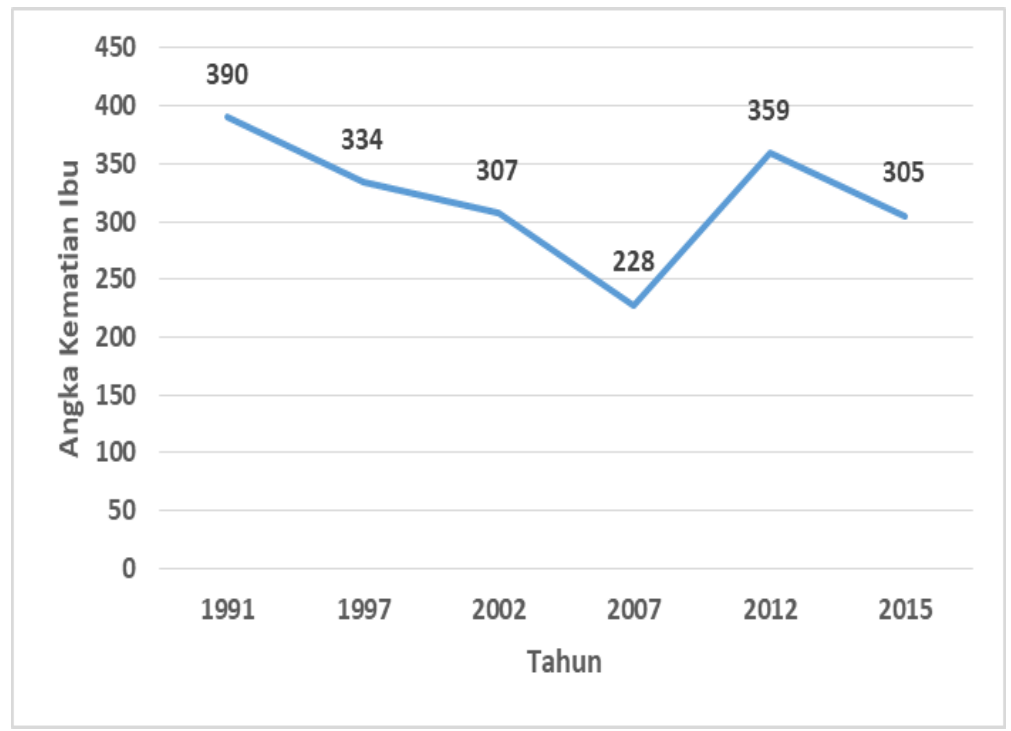

Sumber : SDKI 1991-2012, Supas 2015, diolah

Gambar 2. Angka kematian ibu di Indonesia tahun 1991-2015

Seperti yang terlihat pada Gambar 2, angka kematian ibu (AKI) di Indonesia pada tahun 2015 sebesar 305, yang artinya terdapat 305 kematian ibu per 100.000 kelahiran penduduk. Angka ini masih jauh dari target yang diharapkan dalam Millenium Development Goals (MDGs) untuk tahun 2015 yaitu sebesar 102 (Kemenkes RI,2014). Angka ini juga merupakan titik awal yang masih sangat jauh untuk mencapai target SDGs yaitu sebesar 70 kematian per 100.000 kelahiran hidup pada tahun 2030. AKI di Indonesia berada di peringkat kedua bila dibandingkan dengan negara-negara ASEAN (Aseanstat, 2017). Pada tahun 2012, 11 hingga 14 persen dari angka kematian ibu di Indonesia (359 per 100.000 kelahiran hidup) disebabkan oleh aborsi yang tidak aman. Artinya ada sekitar 43-55 wanita yang meninggal per 100.000 kelahiran hidup karena aborsi yang tidak aman, dimana aborsi dilakukan karena kehamilan tersebut tidak diinginkan (PKBI,2015). KTD mempunyai konsekuensi terhadap ibu, anak, dan kehidupan bermasyarakat sehingga memengaruhi kesehatan mental dan fisik ibu dan anak (Razhegi et al, 2018).

KTD dapat disebabkan oleh beberapa faktor. Menurut Perkumpulan Berencana Keluarga Indonesia (PKBI), penyebab KTD diantaranya psikis perempuan yang belum siap untuk mengalami kehamilan, kegagalan alat konstrasepsi, serta tidak diberikannya hak informasi dan pendidikan seksual pada remaja. Dalam penelitian Anggraeni et al (2018), disebutkan bahwa status pernikahan merupakan faktor paling dominan yang berhubungan dengan KTD. Wanita yang sudah menikah cenderung mengalami KTD 4,5 kali lebih besar dibandingkan dengan wanita yang belum 
menikah. Selain itu, Diasanti dan Sutiawan (2014) mengatakan bahwa penggunaan kontrasepsi memengaruhi kejadian KTD. Pasangan yang mengalami kegagalan kontrasepsi memiliki kecenderungan 8,5 kali untuk mengalami KTD. Kejadian KTD pada daerah pedesaan atau masyarakat tradisonal lebih sedikit, karena masih banyaknya pasangan yang menginginkan jumlah anak yang banyak. Sedangkan pada daerah perkotaan penggunaan alat kontrasepsi sudah tinggi (Sedgh et.al, 2014). Mempelajari faktor-faktor penentu KTD sangat penting, karena akan membantu merancang strategi yang bermanfaat dan intervensi yang hemat biaya untuk mengurangi beban KTD (Aziz et al, 2016).

Melihat banyaknya permasalahan yang merupakan dampak dari KTD, peneliti tertarik untuk mengetahui faktor-faktor yang memengaruhi status kehamilan di Indonesia. Terdapat beberapa tujuan yang ingin dicapai oleh peneliti. Pertama, mengetahui gambaran umum kejadian KTD pada wanita usia subur (15-49 tahun) di Indonesia tahun 2017. Kedua, mengidentifikasi variabelvariabel yang memengaruhi kejadian KTD pada wanita usia subur (15-49 tahun) di Indonesia tahun 2017. Ketiga, menganalisis kecenderungan variabel-variabel yang memengaruhi kejadian KTD pada wanita usia subur (15-49 tahun) di Indonesia tahun 2017.

\section{METODE}

Data

Penelitian ini mencakup seluruh provinsi di Indonesia yang berjumlah 34 provinsi. Unit analisis dalam penelitian ini adalah WUS usia 15-49 tahun yang pernah melahirkan dalam 5 tahun terakhir atau yang sedang hamil saat masa survei. Data yang digunakan merupakan data sekunder dari Survei Demografi dan Kesehatan Indonesia (SDKI) pada tahun 2017 berbentuk raw data. Sampel SDKI 2017 mencakup 1.970 blok sensus yang meliputi daerah perkotaan dan perdesaan. Setelah dilakukan penyaringan dan pembersihan data, jumlah sampel yang digunakan dalam penelitian ini berjumlah 1.631 responden.

Variabel yang digunakan dalam penelitian ini terdiri dari variabel terikat dan variabel bebas. Variabel terikat adalah status kehamilan dengan 3 kategori yaitu diinginkan, tidak tepat waktu (Mistimed pregnancy), dan tidak diinginkan sama sekali (Unwanted pregnancy). Sedangkan variabel bebas terdiri dari umur ibu, jumlah anak masih hidup, penggunaan kontrasepsi, status pernikahan, klasifikasi tempat tinggal, pendidikan ibu, status pekerjaan ibu, dan pengetahuan tentang metode kontrasepsi.

\section{Metode Analisis}

Metode analisis yang digunakan dalam penelitian ini adalah analisis deskriptif dan analisis inferensia. Analisis deskriptif digunakan untuk memberikan gambaran secara umum tentang kejadian KTD berdasarkan umur ibu, pendidikan ibu, status perkawinan, jumlah anak masih hidup, penggunaan kontrasepsi, dan klasifikasi tempat tinggal.

Analisis inferensia yang digunakan adalah regresi logistik multinomial karena variabel terikat yang digunakan memiliki 3 kategori. Regresi logistik multinomial digunakan untuk mengetahui variabel-variabel yang memengaruhi kejadian KTD. Selain itu, penelitian ini juga melihat kecenderungan variabel-variabel yang memengaruhi KTD di Indonesia pada tahun 2017.

\section{Regresi Logistik Multinomial}

Menurut Hosmer dan Lemeshow (2013), regresi logistik merupakan metode analisis statistik untuk menggambarkan hubungan antara variabel terikat ( $Y$ ) yang berupa data kategori dan variabel bebas $(X)$ dapat berupa kategori maupun kontinyu. Regresi logistik multinomial merupakan perluasan dari regresi logistik dikotomi/biner (dua kategori) dengan variabel terikat memiliki kategori lebih dari dua (J) dan variabel bebas berupa data kualitatif maupun kuantitatif.

Tahapan yang dilakukan dalam regresi logistik multinomial adalah sebagai berikut:

1. Pendugaan Parameter

Melakukan pendugaan-pendugaan parameter yang tidak diketahui dengan metode MLE. Model logit yang akan dibentuk yaitu: 
$\widehat{g_{J}}(D)=\widehat{\beta_{J 0}}+\widehat{\beta_{J 11}} D_{j 11}+\widehat{\beta_{J 1}} D_{j 11}+\widehat{\beta_{J 12}} D_{j 12}+\widehat{\beta_{J 2}} D_{j 2}+\widehat{\beta_{J 3}} D_{j 3}+\widehat{\beta_{J 41}} D_{j 41}+\widehat{\beta_{J 4}} D_{j 42}+\widehat{\beta_{J 5}} D_{j 5}+$

$\widehat{\beta_{j 61}} D_{j 61}+\widehat{\beta_{j 62}} D_{j 62}+\widehat{\beta_{j 7}} D_{j 7}+\widehat{\beta_{j 8}} D_{j 8}$

dimana:

$\widehat{g_{J}}(D) \quad$ : persamaan logit untuk kategori ke-j

$\beta_{j 0} \quad$ : estimasi parameter regresi

$\beta_{j 1} \cdots \beta_{j 8} \quad$ : estimasi nilai parameter atau nilai koefeisien regresi

$D_{j 11} \ldots D_{j 8} \quad$ : dummy variable perkategori variablel independen

2. Pengujian signifikansi parameter secara simultan

Pengujian secara simultan dengan uji Likelihood Ratio dilakukan untuk mengetahui pengaruh variabel bebas terhadap kejadian KTD di dalam model secara bersama-sama. Adapun tahapannya sebagai berikut:

- $\quad$ Pengujian hipotesis

$H_{0}: \beta_{j 1}=\beta_{j 2}=\ldots=\beta_{j p}=0$ (tidak ada variabel bebas yang memengaruhi kejadian KTD)

$H_{1}: \beta_{j i} \neq 0$ (minimal ada satu variabel bebas yang memengaruhi kejadian KTD)

- Tingkat signifikansi (a) yang digunakan adalah 5 persen.

- $\quad$ Statistik uji yang digunakan adalah Likelihood Ratio

- Keputusan : tolak $\mathrm{H}_{0}$ jika $G>\chi_{(0,05 ; 22)}^{2}=33,924$ atau p-value $<0,05$

- Kesimpulan : Jika didapatkan keputusan tolak $\mathrm{H}_{0}$, maka dapat dikatakan bahwa minimal ada satu variabel bebas yang memengaruhi KTD secara signifikan.

3. Pengujian signifikansi parameter secara parsial

Uji parsial dapat dilakukan jika pada pengujian secara simultan diperoleh keputusan tolak $\mathrm{H}_{0}$. Pengujian ini menggunakan uji Wald dan bertujuan untuk mengetahui variabel bebas mana saja yang mempengaruhi kejadian KTD pada WUS di Indonesia secara signifikan. Adapun tahapannya sebagai berikut:

- $\quad$ Pengujian hipotesis

$H_{0}: \beta_{j i}=0$ (tidak ada pengaruh variabel bebas ke-i terhadap KTD)

$H_{1}: \beta_{j i} \neq 0$ (ada pengaruh variabel bebas ke-i terhadap KTD)

- $\quad$ Tingkat signifikansi (a) yang digunakan adalah 5 persen.

- $\quad$ Statistik uji yang digunakan adalah Wald Test

- Keputusan : tolak $\mathrm{H}_{0}$ jika $W>\chi_{(0,05 ; 1)}^{2}=3,8415$ atau p-value $<0,05$

- Kesimpulan : Jika didapatkan keputusan tolak $\mathrm{H}_{0}$, maka dapat dikatakan bahwa variabel bebas ke-i secara signifikan memengaruhi KTD.

4. Uji Kesesuaian Model

Uji kesesuaian model atau Goodness of Fit Test digunakan untuk mengetahui kecocokan model yang digunakan dalam penelitian.

- Pengujian hipotesis

$H_{0}$ : model fit/cocol

$H_{1}$ : model tidak fit

- $\quad$ Tingkat signifikansi (a) yang digunakan adalah 5 persen.

- $\quad$ Statistik uji yang digunakan adalah Deviance Chi-Square

- Keputusan : tolak $\mathrm{H}_{0}$ jika $\mathrm{D}>\chi_{(0,05 ; 482)=}^{2} 534,1815$ atau $\mathrm{p}$-value $<0,05$

- Kesimpulan : Jika didapatkan keputusan tolak $\mathrm{H}_{0}$, maka dapat dikatakan bahwa model yang terbentuk tidak cocok.

5. Rasio Kecenderungan

Rasio kecenderungan atau Odds Ratio merupakan nilai eksponensial dari koefisien regresi $(\beta)$. Nilai ini digunakan untuk mengetahui rasio kecenderungan mengalami suatu kejadian tertentu (kategori sukses dan gagal) antara satu kategori dengan kategori lainnya (reference category) dalam suatu variabel. Jika nilai odd ratio-nya lebih dari 1 , maka kecenderungan dari suatu kategori dibandingkan dengan reference category-nya untuk mengalami kejadian sukses lebih besar. Begitu pula sebaliknya, jika nilai odd ratio-nya kurang dari 1, maka kecenderungan dari suatu kategori dibandingkan dengan reference category-nya untuk mengalami kejadian sukses lebih kecil. 


\section{HASIL DAN PEMBAHASAN}

\section{Gambaran Umum Kehamilan Tidak Diinginkan}

Pada Gambar 3, terlihat bahwa ada 83,9 persen merupakan kehamilan diinginkan, 8,3 persen kehamilan tidak pada waktu yang diharapkan, dan 7,8 persen kehamilan yang tidak diinginkan sama sekali di Indonesia pada tahun 2017.

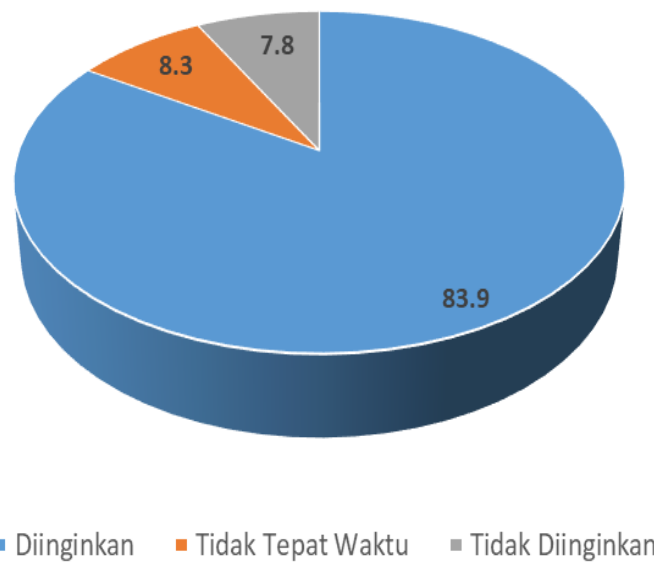

Sumber : SDKI 2017, diolah.

Gambar 3. Persentase Kejadian Kehamilan Tidak Diinginkan di Indonesia Tahun 2017

Pada Tabel 1, terlihat bahwa wanita yang berusia terlalu muda ( $<20$ tahun) kebanyakan mengalami mistimed pregnancy. Sedangkan, wanita yang terlalu tua ( $>35$ tahun) kebanyakan tidak menginginkan anak lagi. KTD mengalami peningkatan seiring dengan bertambahnya jumlah anak. Semakin banyak jumlah anak yang dimiliki oleh wanita maka akan semakin cenderung untuk mengalami kejadian KTD. Kemudian, ibu yang menggunakan kontrasepsi lebih banyak mengalami KTD. Pada status pernikahan, KTD paling banyak dialami oleh wanita yang belum menikah dan selanjutnya diikuti oleh status laiinya yaitu wanita yang cerai hidup, cerai mati maupun tinggal bersama tanpa ikatan pernikahan.

KTD terjadi pada wanita yang tinggal di daerah perkotaan. Pada variabel pendidikan, semakin tinggi pendidikan wanita maka semakin banyak mengalami mistimed pregnancy. Namun, untuk kejadian unwanted pregnancy, lebih banyak terjadi pada wanita yang berpendidikan SD ke bawah. Kemudian, wanita yang bekerja lebih banyak mengalami KTD. Wanita yang mengetahui pengetahuan tentang metode kontrasepsi banyak mengalami KTD.

Tabel 36. Distribusi Persentase KTD Menurut Variabel-Variabel Penelitian

\begin{tabular}{ccccc}
\hline \multirow{2}{*}{ Variabel } & \multicolumn{4}{c}{ Status Kehamilan } \\
\hline \multirow{3}{*}{ Umur } & Diinginkan & $\begin{array}{c}\text { Tidak Tepat } \\
\text { Waktu }\end{array}$ & $\begin{array}{c}\text { Tidak Diinginkan } \\
\text { Sama Sekali }\end{array}$ \\
& $<20$ tahun & 84.5 & 11.3 & 4.2 \\
\cline { 2 - 5 } & $20-35$ tahun & 87.1 & 8.9 & 4.0 \\
\cline { 2 - 5 } Jumlah AMH & $>35$ tahun & 74.4 & 6.1 & 19.6 \\
\cline { 2 - 5 } & $<3$ & 90.5 & 7.5 & 2.0 \\
\hline Penggunaan & $3+$ & 66.5 & 10.3 & 23.2 \\
Kontrasepsi & Tidak Menggunakan & 86.4 & 8.0 & 5.6 \\
\cline { 2 - 5 } Status Pernikahan & Menggunakan & 82.7 & 8.4 & 8.9 \\
\cline { 2 - 5 } & Lainnya & 77.7 & 13.9 & 8.5 \\
\cline { 2 - 5 } & Menikah & 84.2 & 8.0 & 7.8 \\
\cline { 2 - 5 } Klasifikasi Tempat & Belum Menikah & 31.3 & 43.8 & 25.0 \\
\cline { 2 - 5 } Tinggal & Perkotaan & 81.6 & 9.0 & 9.4 \\
\cline { 2 - 5 } & Perdesaan & 86.1 & 7.5 & 6.3 \\
\hline Pendidikan & SD ke bawah & 84.1 & 6.0 & 9.8
\end{tabular}




\begin{tabular}{ccccc}
\hline & Menengah & 84.0 & 8.6 & 7.4 \\
\cline { 2 - 5 } & $>$ SMA & 83.2 & 11.2 & 5.6 \\
\hline \multirow{2}{*}{ Status Pekerjaan } & Tidak Bekerja & 84.4 & 8.1 & 7.5 \\
\cline { 2 - 5 } & Bekerja & 83.4 & 8.5 & 8.1 \\
\hline Pengetahuan & Tidak Mengetahui & 94.1 & 2.0 & 3.9 \\
\cline { 2 - 5 } Kontraepsi & Mengetahui & 83.9 & 8.3 & 7.8 \\
\hline
\end{tabular}

Sumber : SDKI 2017, diolah

\section{Variabel-Variabel yang Memengaruhi Kehamilan Tidak Diinginkan}

Persamaan regresi logistik multinomial yang terbentuk adalah sebagai berikut:

$$
\begin{gathered}
\widehat{g_{1}}(D)=0,871+1,296 D_{j 11}+0,63 D_{112}-0,887 D_{12}-0,238 D_{13}-2,06 D_{141}-2,79 D_{142}+0,206 D_{15}- \\
0,749 D_{161}-0,318 D_{162}+0,08 D_{17}-0,784 D_{18} \\
\widehat{g_{2}}(D)=1,916+0,184 D_{211}-0,703 D_{212}-2,475 D_{22}-0,295 D_{23}-2,776 D_{241}-3,114 D_{242}+ \\
0,661 D_{25}+0,012 D_{261}+0,277 D_{262}+0,037 D_{27}+0,034 D_{28}
\end{gathered}
$$

Keterangan :

$\widehat{g_{1}}(D)$ : persamaan logit untuk kategori kehamilan tidak tepat waktu

$\widehat{g_{2}}(D)$ : persamaan logit untuk kategori kehamilan tidak diinginkan sama sekali

$D_{j 11} \quad$ : dummy variabe/ untuk usia wanita $<20$ tahun

$D_{j 12}$ : dummy variabe/ untuk usia wanita 20-35 tahun

$D_{j 2} \quad$ : dummy variabe/ untuk wanita yang mempunyai anak $<3$ orang

$D_{j 3} \quad$ : dummy variabe/ untuk wanita yang tidak menggunakan kontrasepsi

$D_{j 41} \quad$ : dummy variabe/ untuk wanita yang berstatus lainnya

$D_{j 42} \quad$ : dummy variabe/ untuk wanita yang berstatus sudah menikah

$D_{j 5} \quad$ : dummy variabe/ untuk wanita yang tinggal di daerah perkotaan

$D_{j 61} \quad$ : dummy variabe/ untuk wanita yang tidak bersekolah atau menamatkan SD

$D_{j 62} \quad$ : dummy variabe/ untuk wanita yang menamatkan sekolah menengah

$D_{j 7} \quad$ : dummy variable untuk wanita yang tidak memiliki pekerjaan

$D_{j 8} \quad$ : dummy variable untuk wanita yang tidak mengetahui metode penggunaan kontrasepsi

\section{Pengujian secara simultan}

Pengujian parameter secara simultan dilakukan untuk melihat pengaruh variabel bebas terhadap KTD secara bersama-sama di dalam model. Hasil pengujian parameter secara simultan dapat dilihat dari Tabel 3.

Tabel 3. Hasil uji simultan

\begin{tabular}{lrrrr}
\hline \multicolumn{1}{c}{ Model } & \multicolumn{1}{c}{ Model Fitting Criteria } & \multicolumn{3}{c}{ Likelihood Ratio Tests } \\
\cline { 2 - 5 } & -2 Log Likelihood & Chi-Square & Df & Sig. \\
\hline Intercept Only & 3617,538 & & & \\
\hline Final & 1349,564 & 2267,975 & 22 & 0,000 \\
\hline
\end{tabular}

Dari Tabel 3, terlihat bahwa nilai statistik uji yaitu 2267,975 lebih besar dari $\chi_{(22)}^{2}=33,92$ dan $\mathrm{p}$-value adalah 0,00 dimana angka ini kurang dari $\mathrm{a}=0,05$ sehingga menghasilkan keputusan tolak $H_{0}$. Artinya, dengan tingkat signifikansi 0,05 dapat dikatakan bahwa minimal ada satu variabel bebas yang memengaruhi KTD di Indonesia.

\section{Pengujian secara parsial}

Setelah didapatkan kesimpulan bahwa variabel bebas memengaruhi variabel terikat secara simultan, maka dilanjutkan dengan pengujian masing-masing variabel bebas secara parsial dan didapatkan hasil sebagai berikut.

Tabel 4. Hasil uji parsial

\begin{tabular}{llllll}
\hline Variabel Bebas & Kategori & B & Wald & Sig. & Exp (B) \\
\hline Kehamilan Tidak Tepat Waktu & & & & & \\
\hline
\end{tabular}




\begin{tabular}{|c|c|c|c|c|c|}
\hline \multicolumn{2}{|l|}{ Intercept } & 0,871 & 4,921 & $0,027 *$ & \\
\hline \multirow{2}{*}{ Umur Ibu } & $<20$ tahun & 1,296 & 72,794 & $0,000 *$ & 3,654 \\
\hline & 20-35 tahun & 0,630 & 63,010 & $0,000 *$ & 1,877 \\
\hline Jumlah AMH & $<3$ & $-0,887$ & 185,987 & $0,000 *$ & 0,412 \\
\hline Penggunaan Kontrasepsi & Tidak Menggunakan & $-0,238$ & 14,913 & $0,000 *$ & 0,788 \\
\hline \multirow{2}{*}{ Status Pernikahan } & Lainnya & $-2,060$ & 27,642 & $0,000 *$ & 0,127 \\
\hline & Menikah & $-2,790$ & 53,720 & $0,000 *$ & 0,061 \\
\hline Wilayah Tempat Tinggal & Perkotaan & 0,206 & 13,186 & $0,000 *$ & 1,229 \\
\hline \multirow[t]{2}{*}{ Pendidikan Ibu } & SD ke bawah & $-0,749$ & 66,835 & $0,000 *$ & 0,473 \\
\hline & Menengah & $-0,318$ & 19,094 & $0,000 *$ & 0,728 \\
\hline Status Pekerjaan & Tidak Bekerja & 0,080 & 1,905 & 0,167 & 1,083 \\
\hline Pengetahuan Kontrasepsi & Tidak Mengetahui & $-0,784$ & 2,107 & 0,147 & 0,457 \\
\hline \multicolumn{6}{|c|}{ (Kehamilan Tidak Diinginkan Sama Sekali) } \\
\hline Intercept & 1,916 & & 12,952 & $0,000 *$ & \\
\hline \multirow[t]{2}{*}{ Umur Ibu } & $<20$ tahun & 0,184 & 0,536 & 0,464 & 1,202 \\
\hline & 20-35 tahun & $-0,703$ & 103,140 & $0,000 *$ & 0,495 \\
\hline Jumlah AMH & $<3$ & $-2,475$ & 782,524 & $0,000 *$ & 0,084 \\
\hline Penggunaan Kontrasepsi & Tidak Menggunakan & $-0,295$ & 15,546 & $0,000 *$ & 0,744 \\
\hline \multirow[t]{2}{*}{ Status Pernikahan } & Lainnya & $-2,776$ & 26,498 & $0,000 *$ & 0,062 \\
\hline & Menikah & $-3,314$ & 40,254 & $0,000 *$ & 0,036 \\
\hline \multirow[t]{2}{*}{ Wilayah Tempat Tinggal } & Perkotaan & 0,661 & 99,328 & $0,000^{*}$ & 1,936 \\
\hline & Perdesaan & $0^{\mathrm{b}}$ & & & \\
\hline \multirow[t]{2}{*}{ Pendidikan Ibu } & SD ke bawah & 0,012 & 0,012 & 0,912 & 1,012 \\
\hline & Menengah & 0,277 & 7,300 & $0,007 *$ & 1,319 \\
\hline Status Pekerjaan & Tidak Bekerja & 0,037 & 0,328 & 0,567 & 1,038 \\
\hline Pengetahuan Kontrasepsi & Tidak Mengetahui & 0,074 & 0,026 & 0,872 & 1,076 \\
\hline
\end{tabular}

Keterangan : * signifikan pada $\alpha=0,05$

Variabel yang signifikan memengaruhi KTD adalah variabel yang memiliki nilai $W>\chi_{(0,05 ; 1)}^{2}=$ 3,8415 atau p-value $<0,05$. Pada kategori mistimed pregnancy maupun kategori unwanted pregnancyi, variabel status pekerjaan dan pengetahuan ibu tentang metode kontrasepsi tidak memengaruhi secara signifikan kejadian kehamilan pada wanita usia subur di Indonesia. AbbasiShavazi et al (2004) juga mengatakan bahwa status pekerjaan wanita tidak memengaruhi KTD. Wanita yang bekerja tidak lagi menganggap kehamilan dan anak sebagai penghambat karir mereka. Di Indonesia, wanita yang bekerja dapat menitipkan anaknya kepada pengasuh maupun sanak saudara sehingga tidak dianggap mengganggu kegiatan pekerjaannya. Kemudian, Aziz, Aziz, dan Khuwaja (2016) mengatakan meskipun sudah banyak wanita yang mengetahui dan ingin menggunakan kontrasepsi, masih banyak yang tidak dapat memenuhi kebutuhan kontrasepsinya. Kesadaran tidak selalu menunjukkan kemampuan untuk mendapatkan metode atau menggunakannya dengan benar dan efektif.

\section{Uji Kesesuaian Model}

Setelah melakukan pengujian parameter, selanjutnya dilakukan pengujian kesesuaian model dengan uji Deviance Chi-Square yang dapat dilihat pada Tabel 5.

Tabel 5. Hasil uji kecocokan model

\begin{tabular}{lccc} 
& Chi-Square & Df & Sig. \\
\hline Deviance & 509,368 & 482 & 0,188 \\
\hline
\end{tabular}

Berdasarkan Tabel 5, dapat dilihat bahwa nilai statistik uji sebesar 509,368< $\chi_{(0,05 ; 482)=}^{2} 534,1815$ dan $\mathrm{p}$-value sebesar $0,188<\mathrm{a}=0,05$ sehingga menghasilkan keputusan gagal tolak $H_{0}$. Artinya, dengan tingkat signifikansi 0,05 dapat dikatakan bahwa model yang terbentuk cocok. 


\section{Kecenderungan Kejadian Kehamilan Tidak Diinginkan}

\section{Kecenderungan Kejadian Mistimed Pregnancy}

Nilai odds ratio untuk wanita yang mengalami mistimed pregnancy yang berusia $<20$ tahun adalah 3,654 Artinya, kecenderungan wanita berusia $<20$ tahun untuk mengalami mistimed pregnancy dibandingkan dengan kehamilan yang diinginkan adalah 3,654 kali daripada wanita berusia >35 tahun. Sedangkan, kecenderungan wanita berusia 20-35 tahun untuk mengalami mistimed pregnancy dibandingkan dengan kehamilan yang diinginkan adalah 1,877 kali daripada wanita berusia $>35$ tahun.

Nilai odds ratio untuk wanita yang mengalami mistimed pregnancy yang memiliki anak kurang dari 3 adalah 0,412 kali. Artinya, kecenderungan wanita yang memiliki anak paling sedikit 3 orang untuk mengalami mistimed pregnancy dibandingkan dengan kehamilan yang diinginkan adalah $1 / 0,412$ yaitu 2,427 kali daripada wanita yang memiliki anak kurang dari 3 .

Nilai odds ratio untuk wanita yang mengalami mistimed pregnancy yang tidak menggunakan kontrasepsi adalah 0,788 kali. Artinya, kecenderungan wanita yang menggunakan kontrasepsi untuk mengalami mistimed pregnancy dibandingkan dengan kehamilan yang diinginkan adalah $1 / 0,788$ yaitu 1,269 kali daripada wanita yang tidak menggunakan kontrasepsi.

Nilai odds ratio untuk wanita yang mengalami mistimed pregnancy yang tidak terikat dalam pernikahan adalah 0,127 kali. Artinya, kecenderungan wanita yang belum menikah untuk mengalami mistimed pregnancy dibandingkan dengan kehamilan yang diinginkan adalah 1/0,127 yaitu 7,874 kali daripada wanita yang berstatus cerai hidup/mati. Sedangkan, kecenderungan wanita yang belum menikah untuk mengalami mistimed pregnancy dibandingkan dengan kehamilan yang diinginkan adalah 16,393 kali daripada wanita yang berstatus menikah.

Nilai odds ratio untuk wanita yang mengalami mistimed pregnancy yang tinggal di daerah perkotaan adalah 1,229 kali. Artinya, kecenderungan wanita yang tinggal di daerah perkotaan untuk mengalami mistimed pregnancy dibandingkan dengan kehamilan yang diinginkan adalah 1,229 kali daripada wanita yang tinggal di daerah perdesaan.

Nilai odds ratio untuk wanita yang mengalami mistimed pregnancy yang berpendidikan tertinggi SD ke bawah adalah 0,473 kali. Artinya, kecenderungan wanita yang menamatkan pendidikan lebih tinggi dari SMA untuk mengalami mistimed pregnancy dibandingkan dengan kehamilan yang diinginkan adalah 1/0,473 yaitu 2,114 kali daripada wanita yang berpendidikan SD ke bawah. Sedangkan, kecenderungan wanita yang menamatkan pendidikan lebih tinggi dari SMA untuk mengalami mistimed pregnancy dibandingkan dengan kehamilan yang diinginkan adalah 1,374 kali daripada wanita yang menamatkan tingkat pendidikan SMP ataupun SMA.

\section{Kecenderungan Kejadian Kehamilan Tidak Diinginkan Sama Sekali}

Nilai odds ratio untuk wanita yang mengalami unwanted pregnancy yang berusia 20-35 tahun adalah 0,495 . Artinya, kecenderungan wanita yang berusia $>35$ tahun untuk mengalami unwanted pregnancy dibandingkan dengan kehamilan yang diinginkan adalah 1/0495 yaitu 2,020 kali daripada wanita yang berusia 20-35 tahun.

Nilai odds ratio untuk wanita yang mengalami unwanted pregnancy yang memiliki anak kurang dari 3 adalah 0,084 kali. Artinya, kecenderungan wanita yang memiliki anak paling sedikit 3 orang untuk mengalami unwanted pregnancy dibandingkan dengan kehamilan yang diinginkan adalah 1/0,084 yaitu 11,905 kali daripada wanita yang memiliki anak kurang dari 3.

Nilai odds ratio untuk wanita yang mengalami unwanted pregnancy yang tidak menggunakan kontrasepsi adalah 0,744 kali. Artinya, kecenderungan wanita yang menggunakan kontrasepsi untuk mengalami unwanted pregnancy dibandingkan dengan kehamilan yang diinginkan adalah $1 / 0,744$ yaitu 1,344 kali daripada wanita yang tidak menggunakan kontrasepsi.

Nilai odds ratio untuk wanita yang mengalami unwanted pregnancy yang berstatus cerai hidup/mati adalah 0,062 kali. Artinya, kecenderungan wanita yang belum menikah untuk mengalami unwanted pregnancy yang berstatus cerai hidup / mati. Sedangkan, kecenderungan wanita yang belum menikah untuk mengalami unwanted pregnancy dibandingkan dengan kehamilan yang diinginkan adalah 27,778 kali daripada wanita yang berstatus menikah.

Nilai odds ratio untuk wanita yang mengalami unwanted pregnancy yang tinggal di daerah perkotaan adalah 1,936 kali. Artinya, kecenderungan wanita yang tinggal di daerah perkotaan 
untuk mengalami unwanted pregnancy dibandingkan dengan kehamilan yang diinginkan adalah 1,936 kali daripada wanita yang tinggal di daerah perdesaan.

Nilai odds ratio untuk wanita yang mengalami unwanted pregnancy yang berpendidikan tertinggi SMP-SMA adalah 1,319. Artinya, kecenderungan wanita yang menamatkan tingkat pendidikan SMP ataupun SMA untuk mengalami unwanted pregnancy dibandingkan dengan kehamilan yang diinginkan adalah 1,319 kali daripada wanita yang menamatkan pendidikan lebih tinggi dari SMA.

\section{KESIMPULAN}

Berdasarkan hasil dan pembahasan yang telah dijelaskan sebelumnya, status kehamilan di Indonesia terdiri dari 83,9 persen merupakan kehamilan diinginkan, 8,3 persen mistimed pregnancy yang diharapkan, dan 7,8 persen unwanted pregnancy. Variabel umur ibu, jumlah anak masih hidup, penggunaan kontrasepsi, status pernikahan, wilayah tempat tinggal, dan pendidikan ibu secara signifikan memengaruhi KTD di Indonesia. Kecenderungan wanita mengalami mistimed pregnancy lebih tinggi terjadi pada wanita yang berusia $<20$ tahun, memiliki $\geq 3$ orang anak, menggunakan kontrasepsi, belum menikah, tinggal di perkotaan, dan pendidikan tertinggi >SMA. Sedangkan, kecenderungan wanita mengalami unwanted pregnancy lebih tinggi terjadi pada wanita yang berusia >35 tahun, memiliki minimal 3 anak, menggunakan kontrasepsi, belum menikah, tinggal di daerah perkotaan, dan pendidikan tertinggi SMP atau SMA.

\section{UCAPAN TERIMA KASIH}

Puji syukur penulis ucapkan ke hadirat Allah SWT, karena hanya dengan pertolongan-Nya penulis dapat menyelesaikan makalah ini. Penulis juga mengucapkan terimakasih kepada BKKBN dan Badan Pusat Statistik selaku penyedia data sehingga dapat digunakan oleh penulis dan berbagai pihak yang membutuhkan.

\section{DAFTAR PUSTAKA}

Anggraini, K., Wratsangka, R., Bantas, K., \& Fikawati, S. (2018). Faktor-Faktor yang Berhubungan Dengan Kehamilan Tidak Diinginkan Di Indonesia. PROMOTIF: Jurnal Kesehatan Masyarakat, 8(1), 27-37.

ASEAN Secretariat (2017). ASEAN Statistical Report on Millennium Development Goals 2017.

Aziz Ali, S. A. A., Aziz Ali, S., \& Khuwaja, N. S. (2016). Determinants of unintended pregnancy among women of reproductive age in developing countries: a narrative review. Journal of Midwifery and Reproductive Health, 4(1), 513-521.

Bappenas, BPS, Kemenkes RI (2018). Publikasi Survei Demografi dan Kesehatan Indonesia tahun 2017.

Dini, L. I., Riono, P., dan Sulistiyowati, N. (2016). Pengaruh Status Kehamilan Tidak Diinginkan Terhadap Perilaku Ibu Selama Kehamilan dan Setelah Kelahiran Di Indonesia (Analisis Data SDKI 2012). Jurnal Kesehatan Reproduksi, 7(2), 119-133.

Fitriani, E. (2017). Asuhan Kebidanan Komprehensif pada Kehamilan, Persalinan, Bayi Baru Lahi, Nifas, dan Keluarga Berencana NY.I Usia 24 Tahun di Wilayah Puskesmas 1 Kembaran [Diploma thesis]. Purwekorto: Universitas Muhammadiyah Purwokerto.

Hosmer, D. W., dan Lemeshow, S. (2013). Applied Logistic Regression (3nd ed.) New York : John Willey \& Sons.

Islam, M. M., \& Rashid, M. (2005). Determinants of Unintended Pregnancy Among Ever-Married Women In Bangladesh.

Kementrian Kesehatan Republik Indonesia (2014). Infodatin : Situasi Kesehatan Ibu. Jakarta.

Mohllajee et al. (2007). Pregnancy Intention and Its Relationship to Birth and Maternal Outcomes. Obstet Gynecol, 109 (3), 678-86.

Perkumpulan Keluarga Berencana Indonesia DIY (2015). Diakses pada tanggal 9 November 2019 di https://pkbi-diy.info/perempuan-ktd-tidak-dilindungi-negara.

Razeghi, H., Saadati, M., \& Bagheri, A. (2017). Factors affecting unplanned pregnancy in Semnan province, Iran. Journal of Midwifery and Reproductive Health, 6(2), 1273-1281.

Sedgh G and Ball H. (2008). Abortion in Indonesia, In Brief, (Aborsi di Indonesia, Laporan ini) New York: Guttmacher Institute,No. 2.

Sedgh, G., Singh, S., \& Hussain, R. (2014). Intended and Unintended Pregnancies Worldwide in 2012 and Recent Trends. Stud Fam Plann, Vol. 45 No. 3 : 301-314. 
WHO (2014). Maternal Mortality Ratio. Diakses pada tanggal 8 November 2019 di https://www.who.int/healthinfo/statistics/indmaternalmortality/en/ 